DOI: $10.5613 /$ rzs.46.1.6

\section{Međunarodna konferencija „Euclid Summit: Power to drive positive change. Building civil society and social enterprise knowhow for 2020 and beyond"}

Zagreb, 24.-26. veljače 2016.

»Euclid Summit« je međunarodna konferencija koju organizira Euclid mreža, s ciljem praćenja novih trendova u vještinama i znanjima potrebnim za ostvarivanje većeg utjecaja organizacija civilnog društva i društvenih (socijalnih) poduzeća. Snažni trendovi vezani uz promjene u sferi rada, digitalne tehnologije i nove oblike javnog angažmana prisutni su u društvu i organizacijama te ih preoblikuju i prisiljavaju na promjene u svim sektorima, ali i predstavljaju nove mogućnosti. Euclid mreža europska je mreža lidera trećeg sektora (pojednostavljeno, civilnog društva) i društvenih (socijalnih) poduzetnika te onih koji s njima usko surađuju (više informacija o Euclid mreži dostupno je na www.euclidnetwork.eu). Posvećena je stvaranju veza između civilnog društva i društvenih poduzeća, dijeljenju i proizvodnji vodstva, stručnih i poduzetničkih znanja. Za cilj ima i utjecaj na europske javne politike u financiranju i jačanju angažmana Europske unije te podizanje vidljivosti i razumijevanja civilnog društva i društvenoga (socijalnog) poduzetništva u svim područjima društva.
Skup organiziran krajem veljače 2016. godine u Zagrebu okupio je 155 sudionika iz 28 zemalja. Na njemu su bili zastupljeni osnivači i ravnatelji organizacija civilnog društva i društvenih poduzeća, istraživači, predstavnici investicijskih organizacija i zaklada, voditelji projekata koje financira Europska unija i osobe koje rade na izradi natječaja Europske unije, kao i EU i nacionalni kreatori javnih politika te predstavnici privatnog sektora i društveno odgovornih poduzeća. Program je organiziran tako da su glavne dijelove činila uvodna izlaganja te sekcije vezane uz znanja i vještine (know-how) koje su za temu imale ljude, novac, utjecaj te civilno društvo i društveno poduzetništvo.

Uvodna su izlaganja održali Gojko Bežovan (Pravni fakultet Sveučilišta u Zagrebu) s predavanjem »Barriers and challenges of developing the third sector across Europe: Lessons from the Third Sector Impact EU research project« te Juliet Cornford (Social Enterprise savjetnik iz British Councila) $\mathrm{s}$ temom »Social Enterprise: Important skills for the future«. Gojko Bežovan je predstavio prve rezultate analiza FP7 projekta Third Sector Impact vezane uz području prepreka i izazova razvoju trećeg sektora u Europi. Komparativna analiza više zemalja pokazala je da su neke od glavnih prepreka razvoju nedostatak financijskih sredstava $\mathrm{u}$ vrijeme krize, povećanje opsega birokratskih struktura te prijetnja identitetu organizacija trećeg sektora, od kojih se sve više očekuje da usvajaju oblike djelo- 
vanja slične profitnom sektoru. Mjerenje utjecaja organizacija trećeg sektora također se pokazalo kao važan izazov $\mathrm{u}$ demonstriranju kakav doprinos taj sektor ima na socioekonomski razvoj Europe. Juliet Cornford se fokusirala na budući razvoj društvenih poduzeća. Naglašeno je da će u budućnosti organizacije trećeg sektora morati mnogo više ulagati u razvoj vlastitih vještina kako bi se nosili s izazovima svijeta koji se mijenja.

Sekcije vezane uz znanja i iskustva činile su ključni dio konferencije. U sklopu njih su se sudionici imali priliku upoznati sa suvremenim trendovima i novim alatima za pokretanje pozitivnih promjena. Sekcija orijentirana na temu novca naglasila je ulogu financiranja, napose u smislu generiranja prihoda nakon početne faze razvoja inicijative. Taj se dio fokusirao na različite oblike financijskih modela uključujući socijalno ulaganje te zadružno i socijalno financiranje. Elitsa Barakova, izvršna direktorica bugarske dobrotvorne fondacije BCAF (Bulgarian Charities Aid Foundation) predstavila je izgradnju uspješnih modela prikupljanja sredstava. Ona je, referirajući se na svoje dvadesetogodišnje radno iskustvo, demonstrirala kako biti prilagodljiv i pratiti trendove kroz diverzifikaciju i inoviranje mehanizama doniranja sredstava, posebice onih posredovanih tehnologijom. Daniel Edmiston, istraživač sa Said Business School Sveučilišta u Oxfordu, predstavio je »obveznice socijalnog utjecaja«, njihove mogućnosti te izazove koji predstavljaju za sektor socijalnih inovacija. Pokazuje se da one mijenjaju način na koji organizacije civilnog društva ostvaruju svoju socijalnu misiju te etos ugovaranja i pružanja socijalnih usluga u javnom sektoru.

Sekcija orijentirana na temu ljudi naglasila je da je odnos s dionicima ključan i poseban naglasak stavila na vještine vodstva u razvijanju organizacija. Sandy Farquharson te John Wilkes predstavili su udrugu vodećih ljudi škotskih dobrovoljnih organizacija (Association of Chief Officers of Scottish Voluntary Organisations) i njihov Leadership Excellence Framework, opisujući skup ključnih kompetencija usmjerenih na povećanje sposobnosti vodstva. To je alat namijenjen vođenju i podržavanju lidera civilnog društva u poboljšanju ne samo rada pojedinca i njihovih organizacija, nego i civilnog društva u cjelini.

Sekcija orijentirana na temu utjecaja usredotočila se na načine mjerenja utjecaja, odnosno učinka koju organizacije stvaraju, ali i njegova komuniciranja široj zajednici. Carlos Azevedo, ravnatelj IES Social Business School iz Portugala predstavio je »generator društvene vrijednosti«. To je okvir koji se može koristiti za izgradnju, projektiranje i ocjenu održivog rješenja za određeni društveni problem. Proces uključuje tri faze: 1. identificiranje problema, 2. stvaranje vrijednosnih propozicija $i$ 3. dizajniranje rješenja. »Measuring the difference: Models, Mission \& Skills« bio je naslov izlaganja Gorgia Krleva s Centra za socijalne investicije iz njemačkog Heidelberga. Kvantificiranje 
utjecaja izaziva sve više zanimanja, a prikaz se temeljio na različitim pristupima mjerenja utjecaja koje Centar prakticira. Autor se osvrnuo i na neka od ključnih pitanja koje je potrebno riješiti u procesu mjerenja utjecaja i vještina nužnih u razvijanju pristupa socijalnog povrata investicija.

U drugom danu održavanja skupa bile su zastupljene dvije sekcije o znanju i vještinama, jedna vezana uz razvoj civilnog društva i jedna uz razvoj društvenog poduzetništva. Suosnivačica danske organizacije Social+ Anne Bergvith Sørensen u okviru rada svoje organizacije u zadnjih je nekoliko godina radila s više od stotinu organizacija razvijajući socijalne inovacije u trećem i javnom sektoru. Ona je podijelila svoje uvide o ključnim aspektima procesa stvaranja dobrih ideja i vođenja pozitivne promjene. Zagovaranje u praksi predstavili su Daniel Ferrer, projektni voditelj u španjolskoj zakladi Pere Tarres i Monica Plana, direktorica španjolske udruge za dobrobit i razvoj ABD. Oni su sa sudionicima skupa podijelili različite slučajeve dobre prakse zagovaranja te pružili prigodu da se sagleda kako zagovaranju u praksi osigurati još veći utjecaj.

U sklopu sekcije koja je tematizirala znanje i vještine za društveno poduzetništvo predstavljena je Zadruga za etično financiranje. Goran Jeras, upravitelj te zadruge, podijelio je sa sudionicima svoje dosadašnje iskustvo pri pokušaju osnivanja prve etične banke u Hrvatskoj. Ebanka, koja bi uskoro trebala početi s poslovanjem, služit će kao servis za društvenu zajednicu podupiranjem ulaganja na lokalnoj razini kao što su održiva ekološka poljoprivreda, nove tehnologije, inovacije te društveno poduzetništvo. Laura Montenegro, iz britanske organizacije Social Investment Business predstavila je vještine koje organizacije trebaju razviti interno i steći iz vanjskog okruženja kako bi se osigurali novi oblici ulaganja koji se oslanjaju na izgradnju kapaciteta $i$ poboljšanje izvedbe za povećanje društvenog utjecaja.

Osim spomenutih sadržaja, skup je osigurao značajan prostor za umrežavanje i izgradnju suradnji među praktičarima. Zasebna sesija »EU network-building space« održana je na kraju prvog dana te omogućila sudionicima da prošire svoje mreže potencijalnih partnera unutar projekata Europske unije. Planirane su suradnje na budućim projektima u okviru programa Erasmus + , Horizon 2020 i unutar programa Erasmus za mlade poduzetnike. Večer prvog dana bila je posvećenja neformalnom obli$\mathrm{ku}$ razvoja suradnji kroz programski sadržaj »Knowhow late cafés«, koji je pružio mogućnost daljnje elaboracije suradnje i otvorenog razgovora. Tematski okviri bili su socijalne inovacije kroz suradnju, stvaranje poticajnog okruženja za društveno poduzetništvo te izgradnja održivog partnerstva za društvena poduzeća.

Skup je potaknuo uzajamno učenje i umrežavanje. Izgradnja održivih partnerstava i suradnji sagledana je kao ključan doprinos za razvijanje socijalnih inovacija i održivost društvenih podu- 
zeća. Mjerenje učinka koje organizacije stvaraju i hvatanje stvorene društvene vrijednost još su uvijek među ključnim izazovima s kojima se treći sektor suočava. »Euclid Summit« je naglasio da taj sektor ima potrebu i zadaću kontinuirano razvijati svoje sposobnosti kako bi pozitivnom društvenom promjenom mogao utjecati na svijet koji se brzo mijenja i koji je opterećen novim socijalnim rizicima.

Danijel Baturina

Studijski centar socijalnog rada, Pravni fakultet Sveučilišta u Zagrebu

DOI: $10.5613 /$ rzs.46.1.7

\section{Međunarodna konferencija »Religion and Non-Religion in Contemporary Societies. Theoretical, Empirical and Methodological Challenges for Research in Central and Eastern Europe and Beyond"}

Zadar, 21.-24. travnja 2016.

U organizaciji ISORECEA-e (International Study of Religion in Eastern and Central Europe Association) i Istraživačke mreže za sociologiju religije (Sociology of Religion Research Newtork) Europskoga sociološkog društva te $\mathrm{u}$ suradnji s Odjelom za sociologiju Sveučilišta u Zadru i Hrvatskim sociološkim društvom, održana je međunarodna kon- ferencija »Religion and Non-Religion in Contemporary Societies. Theoretical, Empirical and Methodological Challenges for Research in Central and Eastern Europe and Beyond « u Zadru od 21. do 24. travnja 2016. godine. To je ujedno i 12. konferencija ISORECEA-e, koja je među redovnim, ali i novim, izlagačima i sudionicima već stekla poštovanja vrijednu tradiciju i velik ugled.

U predgovoru Knjige sažetaka njezini urednici i organizatori konferencije Dinka Marinović Jerolimov i Siniša Zrinščak ističu da se u pripremi teme konferencije željelo naglasiti »međuigru povijesnih, kulturnih i političkih čimbenika i događaja koji su pridonijeli činjenici da su u suvremenim društvima jednako važni procesi povezani s religijom kao i nereligijom«. Napominju i da "nereligija« kao pojam i proces još uvijek ne dobiva dovoljno teorijske razrade i empirijske pozornosti, uključujući društva poput bivših socijalističkih zemalja u kojima je ateizam predstavljao vladajuću ideologiju. Urednici osobito ističu izniman interes autora za sudjelovanje na konferenciji, što je rezultiralo s 92 izlaganja u (su)autorstvu 111 izlagača, odnosno 101 sudionikom konferencije iz 20 europskih zemalja, Kanade, Sjedinjenih Američkih Država, Južne Koreje, Indije i Pakistana.

U sklopu konferencije održana su dva plenarna izlaganja. Lois Lee, istraživačica s Instituta za napredne studije (University College London), govorila je na temu pod naslovom »Secularisation without the secular: Understanding religion and nonreligious in a 